\title{
The Male Reproductive System and the Effect of an Extract of a Medicinal Plant (Hypericum perforatum) on the Labeling Process of Blood Constituents with Technetium- 99m
}

\author{
Sebastião David Santos-Filho ${ }^{1,2} *$, Adenilson de Souza da Fonseca ${ }^{1}$ and Mario Bernardo- \\ Filho $^{1,3}$ \\ ${ }^{1}$ Laboratório de Radiofarmácia Experimental; Departamento de Biofísica e Biometria; Instituto de Biologia \\ Roberto Alcantara Gomes; Universidade do Estado do Rio de Janeiro; Av. 28 de setembro, 87; 20551-030; \\ santos-filho@uerj.br; Rio de Janeiro - RJ - Brasil. ${ }^{2}$ Programa de Pós-Graduação em Ciências da Saúde; Centro de \\ Ciências da Saúde; Universidade Federal do Rio Grande do Norte; A. Gal. Gustavo Cordeiro de Farias, s/n; \\ 59010-180; Natal - RN - Brasil. ${ }^{3}$ Coordenadoria de Pesquisa; Instituto Nacional do Câncer; Praça Cruz Vermelha, \\ 23; 20230-130; Rio de Janeiro - RJ - Brasil
}

\begin{abstract}
Hypericum perforatum (hiperico) is a plant that has been used to treat diseases and also inhibits rat and human vas deferens contractility. In nuclear medicine, stannous chloride $\left(\mathrm{SnCl}_{2}\right)$ is used as a reducing agent to obtain radiopharmaceuticals labeling with technetium-99m. As the $\mathrm{SnCl}_{2}$ seems to have adverse effects related with the reproductive performance of male rabbits as well as the human consumption of hiperico might affect sexual function. In the present work, consistent results show significant changes on the blood constituents labeled by technetium-99m obtained from young rats under the effect of an hiperico extract as opposed to blood samples equally treated taken from elderly rat.. Supposedly, this extract could protect the male reproductive system against action of $\mathrm{SnCl}_{2}$ at least in young rats. The findings described in this work allow introducing a simple assay to evaluate the action of products that could interfere with the male reproductive system.
\end{abstract}

Key words: Stannous chloride, young animals, elderly animals, sexual function, Technetium-99m, Hypericum perforatum

\section{INTRODUCTION}

Sexual dysfunctions are common among the general population and can affect the male reproductive system, as the sperm production and the ejaculation. Several authors (Wu et al.1996; Naha and Chowdhury 2006; Kumar et al., 2006) have reported that metal ions such as iron, lead, chromium, manganese, tin and cadmium adversely affect the male reproductive. Agarwal et al..(2006) have published a review about the role of free radicals and oxidative stress in the pathophysiology of human reproduction and they suggest that the oxidative stress and sperm DNA damage have been implicated in male infertility. Elevated levels of oxygen reactive species are correlated to the poor fertility outcomes seen in the assisted reproductive technology setting and it is

\footnotetext{
${ }^{*}$ Author for correspondence
} 
indicated that an accurate evaluation of seminal oxidative stress by standardized assays may help in the diagnosis and management of male infertility. There is evidence in the literature on the beneficial effects of oral antioxidant supplementation of vitamins in male infertility (Agarwal et al., 2006; Menezo et al., 2007).

Tin is a heavy metal, which has long been regarded as a contaminant of the environment (Wood, 1974). One of its inorganic salts, stannous chloride $\left(\mathrm{SnCl}_{2}\right)$, has been widely used in daily human life, to conserve preserve soft drinks, in food manufacturing, as a result of processing and packaging and in biocidal preparations (de Mattos et al., 2000). In nuclear medicine, $\mathrm{SnCl}_{2}$ is used as a reducing agent of technetium-99m (99mTc), as sodium pertechnetate, the most used radionuclide to obtain several radiopharmaceuticals which are also used in the single photon emission computed tomography (SPECT). In addition, it has been also used as a radiotracer to label different cells and molecules of interest to scientific research (Saha, 2004). It was demonstrated that tin, as $\mathrm{SnCl}_{2}$, can facilitate the neuromuscular transmission by accelerating the transmitter release from the nerve terminals in the mouse (Hattori et al., 1989). When this salt is injected into laboratory animals, it can produce stimulation or depression of the central nervous system. Because calcium $(\mathrm{Ca} 2+)$ influx into the cytoplasm is indispensable to release the transmitter, it would be possible that $\mathrm{SnCl}_{2}$ increases the $\mathrm{Ca} 2+$ influx at the nerve terminals but not by blocking the $\mathrm{K}+$ channels (Hattori et al., 1994). $\mathrm{SnCl}_{2}$ is known to (i) inhibit the immune response in rodents (Hayashi et al., 1984), (ii) alter the gene expression (Helvig et al., 1998) and (iii) induce tumor generation in thyroid gland (Babar et al., 1991). There is no general agreement regarding its genotoxicity and it was discussed that the effects of this salt might depend on the physicochemical conditions and the route of its administration. This salt is directly administered to human beings, intravenously, when it is used as a reducing agent to prepare $99 \mathrm{mTc}$ radiopharmaceuticals (Saha, 2004). Stannous chloride is capable of inducing the generation of free radicals that seem to be implicated with the oxidative stress (Caldeira-de-Araujo et al., 1996; Dantas et al., 1996; Dantas et al., 1999; Yousef et al., 2007).

Yousef (2005) has studied the protective role of ascorbic acid on reproductive performance of male rabbits given sublethal dose of tin, as stannous chloride. The results showed that treatment with $\mathrm{SnCl}_{2}$ caused a statistical decrease in the libido, ejaculate volume, sperm concentration, total sperm output, percentage of the sperm motility, total motile sperm per ejaculate, packed sperm volume, total functional sperm fraction, normal and live sperm and semen initial fructose. Dead sperm and initial hydrogen ion concentration were increased, while relative weights of testes and epididymis were decreased. The results obtained suggest that assessment of reproductive toxicity of $\mathrm{SnCl}_{2}$ needs to be addressed, and may presently be underestimated. Also, the beneficial influence of ascorbic acid in counteracting the toxic effects of $\mathrm{SnCl}_{2}$ and improved the reproductive performance of male rabbit was demonstrated.

Due to the high relevance of the stannous salts, several authors have reported different experimental models in various levels of organization to try to study its redox properties, as well as to try to identify products (natural and synthetic) that could reduce or abolish the effect of the stannous salts. Melo et al..(2001) have reported studies with Escherichia coli cultures evaluating the influence of crude extracts on the survival of the strain submitted to $\mathrm{SnCl}_{2}$. Fonseca et al..(2005) have described evaluation of the effect of Acetylsalicylic acid on the labeling of blood constituents with 99mTc. Yousef (2005) has reported studies with the protective effect of the ascorbic acid to enhance reproductive performance of male rabbits treated with stannous chloride.

As natural products are also increasingly available in most industrialized countries of the world, the use of the techniques allows to evaluate their biological and chemical properties become highly relevant. The labeling of blood constituents with $99 \mathrm{mTc}$ is a simple technique that has been used to investigate redoxi properties of different natural products, as Paullinia cupana (Oliveira et al., 2002), propolis (Jesus et al., 2006), Fucus vesiculosus (Oliveira et al., 2003). In this technique is used a reducing agent, the stannous chloride. The compounds present in the natural extract with oxidant property will oxidize the stannous ion and the labeling of blood constituents will decrease.

Hypericum perforatum (St John's wort or hiperico) is an herbal medicine that has been widely used to treat several diseases. Several studies have been performed to try to identify properties of this phytotherapeutic agent. Meta-analytical studies show that St John's wort extracts are more 
effective than placebo in patients with mild and moderate depression (Newall et al., 1996; Werneke et al., 2004) and dysthymia (Rotblatt and Ziment, 2002). This plant also has been used as antiviral and diuretic, and to treat diarrhea, dyspepsia, parasites, neuralgia, sciatica and rheumatism (Rotblatt and Ziment, 2002). Wang et al.(2001) have reported that some components of St John's wort interfere with CYP3A4, one of the main cytochrome P450 isoenzymes. CYP3A4 is involved in the metabolism of many commonly used drugs. St John's wort can interact with medicines that can result in serious toxicological effects (Cordeiro et al., 2005). Mannel (2004) and Wada et al.(2002) have described that the St John's wort reduces the efficacy of several pharmacological compounds including, immunosuppressants (risk of graft rejection), oral contraceptives (risk of pregnancy), oral anticoagulants (risk of thrombosis), and HIV protease inhibitors. It has pharmacodynamic effects on neuronal excitability (Neagoe et al., 2004). Sosa et al.(2007) suggested that different constituents of St John's wort have been involved in anti-inflammatory activity. Capasso et al.(2005) have reported that the St John's wort directly inhibits rat and human vas deferens contractility. Moreover, it is supposed that, if confirmed in vivo, these results might affect sexual function in humans and, moreover, these results might explain the delayed ejaculation described in patients receiving St John's wort. Also, the $\mathrm{SnCl}_{2}$ seems to generate free radicals that may be related to undesirable effects in the reproductive performance of male rabbits as well as the Hypericum perforatum might affect sexual function in humans.

The aim of this work is to present results about the effect of an extract of this medicinal plant (Hypericum perforatum) on the labeling process of blood constituents with $99 \mathrm{mTc}$, in which is used stannous chloride as reducing agent to further correlate with other physiological changes.

\section{MATERIAL AND METHODS}

The protocols of the experiments were performed without sacrificing the animals and was approved (CEA/113/2006) by the Ethical Committee of the Instituto de Biologia Roberto Alcantara Gomes, Universidade do Estado do Rio de Janeiro.
Heparinized whole blood was withdrawn by cardiac puncture from male Wistar rats, 9 animals, 3 months of age (young animals) and $293 \pm 13 \mathrm{~g}$ of weight, and from male Wistar rats, 9 animals, 6 months of age (elderly animals), $359 \pm 22 \mathrm{~g}$ of weight.

The extract of St John's wort was prepared with $5 \mathrm{~g}$ of dust of Hypericum perforatum (Herbarium Laboratório Botânico LTDA, Brazil, lot 954661) in $100 \mathrm{ml}$ of $0.9 \% \mathrm{NaCl}$. The preparation was homogenized in a vortex mixer and filtered through paper (quality filter paper) and $1 \mathrm{ml}$ of the filtered solution was considered to have $50 \mathrm{mg}$ of the extract and it was denoted as $100 \%$. The quality control of this extract was evaluated with the analysis of the absorption spectra of a Hypericum perforatum extract recorded in the range from 400 up to $700 \mathrm{~nm}$ with intervals of $20 \mathrm{~nm}$ using a spectrophotometer (Analyser $800 \mathrm{M}$, Analyser Comércio e Indústria LTDA, São Paulo, Brazil), using a cuvette of $1 \mathrm{~cm}$ pathlength. All spectrophotometric measurements were performed on the same spectrophotometer and the value of the absorbance at $580 \mathrm{~nm}(0.414 \pm 0.016)$ was used as a marker and the quality control of each prepared hiperico extract in the all experiments.

The tubes used in these experiments were previously closed with a rubber cap and a syringe was used to reduce the air atmosphere (vacuum) inside the vials.

Blood samples $(0.5 \mathrm{ml})$ either from young or elderly animals were incubated with $100 \mu \mathrm{l}$ of $\mathrm{St}$ John's wort extract $(50 \mathrm{mg} / \mathrm{ml})$ for 1 hour at room temperature. Samples of heparinized whole blood were incubated with saline solution $(0.9 \% \mathrm{NaCl})$ as control. Then, $0.5 \mathrm{ml}$ of a freshly prepared stannous chloride solution $(1.2 \mu \mathrm{g} / \mathrm{ml})$, as $\mathrm{SnCl}_{2}$ (Sigma, USA) was added and the incubation continued for another 1 hour. After this period of time, $99 \mathrm{mTc}(0.1 \mathrm{ml})$, as sodium pertechnetate, recently milked from a $99 \mathrm{Mo} / 99 \mathrm{mTc}$ generator (Instituto de Pesquisas Energéticas e Nucleares, Comissão Nacional de Energia Nuclear, Brazil), was added and the incubation continued for another $10 \mathrm{~min}$. These samples were centrifuged and plasma (P) and BC cells were separated. Samples $(20 \mu \mathrm{l})$ of $\mathrm{P}$ and $\mathrm{BC}$ were also precipitated with $1 \mathrm{ml}$ of trichloroacetic acid (TCA) $5 \%$ and soluble (SF) and insoluble fractions (IF) were separated. The radioactivity in P, BC, IF-P, SF-P, IF-BC and SF-BC were determined in a well counter (Automatic Gamma Counter, Packard 
Instrument Co, Illinois, USA). After that, the percentage of radioactivity (\%ATI) was calculated as described elsewhere (Bernardo-Filho et al., 1990; Bernardo-Filho et al., 1994; Lima-Filho et al., 2003).

Statistical analysis involved one-way ANOVA, followed by the Turkey-Kramer Multiple Comparisons Test, with the significance level being $P<0.05$. InStat Graphpad software was used to perform statistical analysis (GraphPad InStat version 3.01 for Windows 95/NT, GraphPad Software, San Diego Ca, USA).

\section{RESULTS}

Fig. 1 shows the distribution of the radioactivity in the cellular and plasma compartments isolated from whole blood from young or elderly animals treated with the St John's wort extract and saline solution. The results indicates that there is a significant decrease $(P<0.05)$ in radioactivity distribution of the $99 \mathrm{mTc}$ in the cellular compartment in presence of St John's wort extract from $95.02 \pm 0.51$ to $4.15 \pm 0.91$ when blood from young rats was used. However, when the blood from elderly rats was used, the St John's wort extract was not capable to interfere in the distribution of radioactivity in the cellular and plasma compartments.

The results in Fig. 2 indicate that there is a significant $(P<0.05)$ decrease in the radionuclide fixation by the plasma proteins (IF-P) isolated from whole blood (young animals) treated with $\mathrm{St}$ John's wort extract from $76.24 \pm 6.15$ to $26.67 \pm 1.70$. However, when the blood from elderly rats was used, the St John's wort extract was not capable to interfere in the fixation of radioactivity in the plasma proteins (IF-P).

The results shown in Fig. 3 indicate that there is a significant $(P<0.05)$ decrease in the radioactivity fixation in the cellular proteins (IF-BC) isolated from whole blood (young animals) treated with $\mathrm{St}$ John's wort extract from $95.73 \pm 0.33$ to $14.82 \pm 0.61$. The fixation of radioactivity in the cellular proteins (IF-BC) obtained form elderly animals has also diminished, and although this decrease would be significant $(P<0.05)$, it was only a small alteration (from $90.75 \pm 1.25$ to 82.12 \pm 5.05$)$.

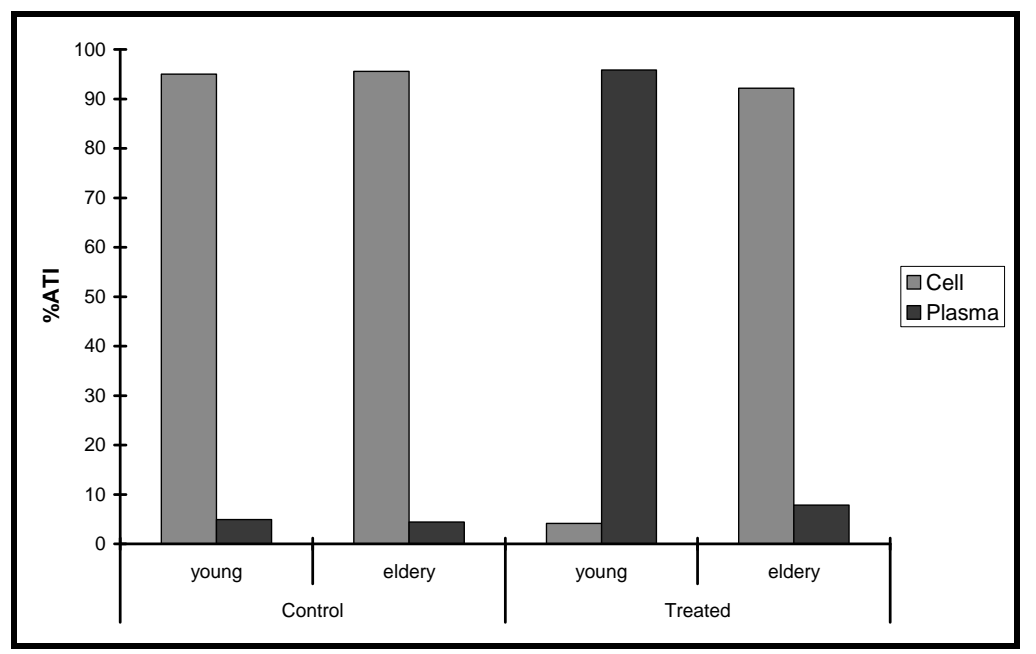

Figure 1 - Assessment of the effects of Hypericum perforatum extract on the distribution of the radioactivity in the cellular (cel) and plasmatic (plasma) compartments on blood of young and elderly animals. 


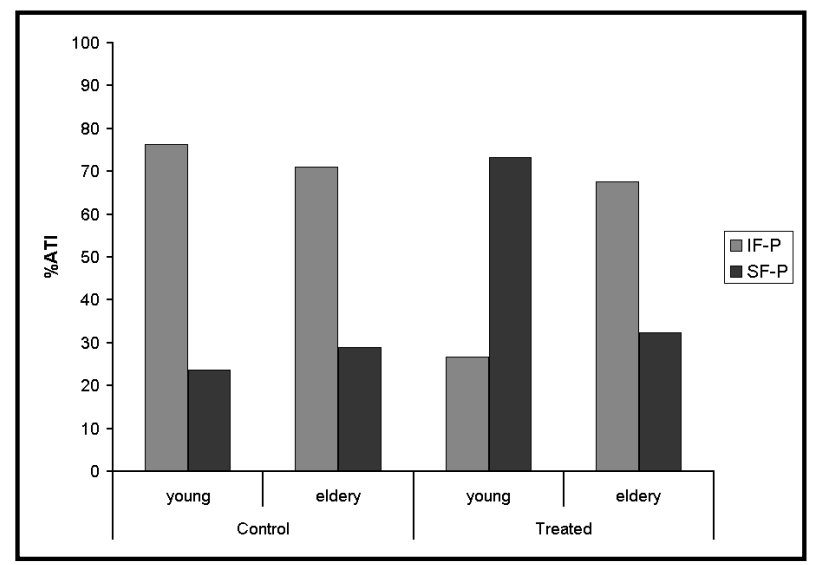

Figure 2 - Assessment of the effects of Hypericum perforatum extract in the labeling with $99 \mathrm{mTc}$ of soluble (SF) and insoluble (IF) fractions of the plasma (P) on young and elderly animals.

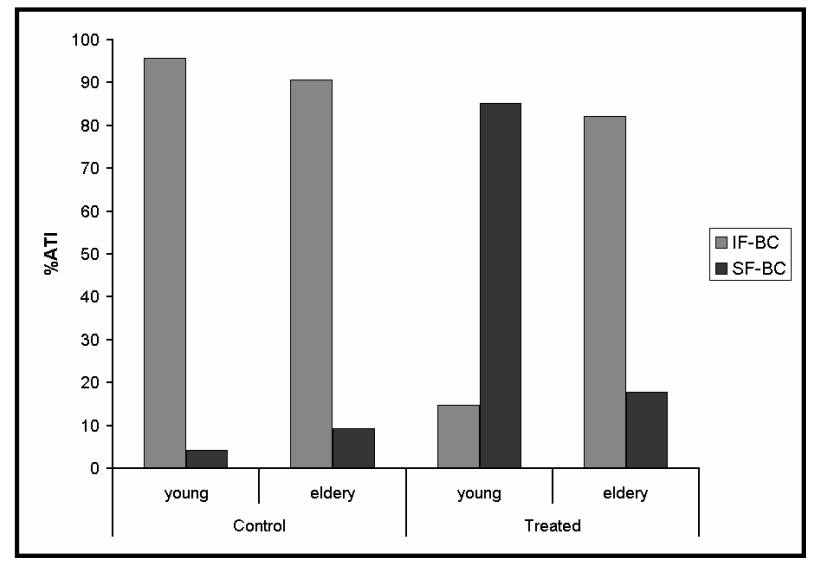

Figure 3 - Assessment of the effects of Hypericum perforatum extract in the labeling with $99 \mathrm{mTc}$ of soluble (SF) and insoluble (IF) fractions of the BC of young and elderly animals.

\section{DISCUSSION}

The physiology of the ejaculation includes emission of sperm with the accessory gland fluid into the urethra, simultaneous closure of the urethral sphincters, and forceful ejaculation of semen through the urethra. The quality of this sperm can be affected in several conditions. Due to the industrialization processes, the human beings have an important direct or indirect exposition to some metals that can adversely affect the male reproductive system by directly acting on the sperm plasma membrane or by catalyzing the generation of free radicals (Wu et al., 1996; Naha and Chowdhury 2006; Kumar et al, 2006). Metal chelators control lipid peroxidation of the sperm plasma membrane and protect the integrity of the spermatozoon, and also prevent DNA damage (Guthrie and Welch, 2007). Albumin, ceruloplasmin, and metallothionein are proteins that interact with iron and cooper and decrease the free radicals formation (Yousef; 2005; Agarwal et al., 2006).

The development of experimental models to try to verify the capability of a product to avoid the oxidation of the metals or to be a metal chelator is worthwhile. A model using a reducing agent could be useful due to it would be possible to study the 
oxidant property of some chemical products, as the medicinal plants. The oxidation of a reducing agent, as the stannous chloride, it might be convenient to prevent about their biological effects as the generation of free radicals. Free radicals generated due to the presence of stannous chloride could cause deterioration in the semen quality and could be undesirable to the male rabbits reproductive performance (Yousef, 2005).

The extract of hiperico was capable to interfere on the fixation of the Tc-99m on the blood constituents when blood withdrawn from young rats was used (Fig. 1, 2 and 3). This extract could have an action similar to the vitamin $\mathrm{C}$, as reported by Agarwal et al (2006) that has suggested that vitamin $\mathrm{C}$ would neutralize hydroxyl, superoxide, and hydrogen peroxide radicals. In addition, it would also help recycle vitamin $\mathrm{E}$, which would neutralize $\mathrm{H}_{2} \mathrm{O}_{2}$ and would protect the plasma membrane from lipid peroxidation. It is also possible to argue that hiperico extract could act directly or indirectly (generation of free radicals), leading to the oxidation of the stannous salt. In this case, it would be possible to speculate that the stannous chloride could have a similar action to the vitamin $\mathrm{C}$ in the experimental model used by Yousef (2005). Moreover, Capasso et al (2005) have reported that the St John's wort directly inhibits rat and human vas deferens contractility. Moreover, it is supposed that, if confirmed in vivo, these results might affect sexual function in humans and, these results might explain the delayed ejaculation described in patients receiving St John's wort.

Some authors have reported that the free radical hypothesis states that aging results from random deleterious events, and that self-inflicted oxidative damage is the primary contributor to such a stochastic degeneration of organisms. The hypothesis has been supported by experimental data that demonstrate that steady-state levels of oxidation-damaged macromolecules increase with age (Orr and Sohal, 1994; Parkes et al, 1998; Sun et al, 2002). Some attempts have been made to correlate oxidation with a reduced activity of the oxidative defense systems. However, these attempts have generated conflicting results and catalases have been demonstrated either increase or decrease with the age, depending on the tissues or organisms analyzed. Other studies have demonstrated that the abundance of some antioxidant defense proteins may actually increase with age in some tissues. Similarly, in a reproductively arrested population of $E$. coli cells, the levels of oxidative defense proteins increase and the population becomes increasingly resistant to external oxidative stresses (Matin, 1991; Hengge-Aronis, 2000). These findings could aid understanding that the extract of hiperico was not capable of interfering on the fixation of the Tc$99 \mathrm{~m}$ on the blood constituents when blood withdrawn from elderly rats was used (Figs. 1 and 2).

In conclusion, the findings described here allow setting the bounds for a new assay to evaluate the action of products that could interfere with the male reproductive system. Moreover, the hiperico seems to alter the labeling of blood constituents with $99 \mathrm{mTc}$ isolated from whole blood of young animals. Then, it is supposed that this hiperico extract could protect the male reproductive system against action of metals, as the stannous chloride, at least in young rats.

\section{ACKNOWLEDGMENTS}

We are grateful to Mr. Carlos Brown Scavarda (B.A., UNIVERSITY OF MICHIGAN) for the English language revision. Financial support: CNPq, CAPES and UERJ.

\section{RESUMO}

Hypericum perforatum (hiperico) tem sido utilizado para tratar diferentes distúrbios e também inibir a contractilidade do ducto deferente em ratos e em humanos. Na medicina nuclear, o cloreto estanoso $\left(\mathrm{SnCl}_{2}\right)$ é usado como um agente redutor para obter radiofármacos marcados com tecnécio99m. Como o $\mathrm{SnCl}_{2}$ parece acarretar efeitos indesejáveis relacionados com o desempenho reprodutivo de coelhos machos e o hiperico pode afetar a função sexual em humanos, o objetivo desse trabalho é apresentar resultados sobre o efeito de um extrato de hiperico na marcação de constituintes sangüíneos com o tecnécio-99m retirados de ratos jovens e idosos. O hiperico parece alterar a marcação de constituintes sangüíneos com tecnécio-99m isolados de sangue de animais jovens. Embora, esse resultado não seja observado em ratos idosos. Provavelmente, o extrato poderia apresentar uma ação protetora para o sistema reprodutivo contra a ação do $\mathrm{SnCl}_{2}$, pelo 
menos em ratos jovens. Os resultados descritos nesse trabalho permitem introduzir um ensaio simples para avaliar a ação de produtos que poderiam interferir com o sistema reprodutor masculino.

\section{REFERENCES}

Agarwal, A.; Gupta, S. and Sikka, S. (2006). The role of free radicals and antioxidants in reproduction. Curr Opin Obstet Gynecol. 18, 325-332.

Agarwal, A.; Said, T. M.; Bedaiwy, M. A.; Banerjee, J. and Alvarez, J. G. (2006). Oxidative stress in an assisted reproductive techniques setting. Fertil Steril. (epud ahead of print).

Babbar, A., Kashyap, R. and Chauhan, U. P. (1991). A convenient method for the preparation of $99 \mathrm{mTc}$ labelled pentavalent DMSA and its evaluation as a tumour imaging agent. J Nucl Biol Med. 35, 100-104.

Beckmann, S. E.; Roger, W. S. and Switzer, J. (2000). Consumer use of St. John's wort: a survey of effectiveness, safety and tolerability. Pharmacotherapy. 20, 568-574.

Bernardo-Filho, M.; Gutfilen, B. and De Souza Maciel, O. (1994). Effect of different anticoagulants on the labeling of red blood cells and plasma proteins with 99mTc. Nucl Med Commun. 15, 730-734.

Bernardo-Filho, M.; Nogueira, J. F.; Sturm, J. A. and Boasquevisque, E. M. (1990). Plasma proteins labeling with 99mTechnetium. Arq Biol Technol. 33, 811-817.

Caldeira-de-Araujo, A.; Dantas, F. J. S.; Moraes, M. O.; Felzenszwalb, I. and Bernardo-Filho, M. (1996). Stannous chloride participates in the generation of reactive oxygen species. J Braz Assoc Adv Sci. 48, 109-113.

Capasso, R.; Borrelli, F.; Montanaro, V.; Albieri, V.; Capasso, F. and Izzo, A. A. (2005). Effects of the antidepressant St. John's wort (Hypericum perforatum) on rat and human vas deferens contractility. J Urol. 173, 2194-2197.

Cordeiro, C. H. G.; Chung, M. C. and Sacramento, L. V. S. (2005). Interações medicamentosas de fitoterápicos e fármacos: Hypericum perforatum and Piper methysticum. Rev Bras Farmacogn. 15, 272278.

Dantas, F. J. S.; Moraes, M. O.; Carvalho, E. F.; Valsa, J. O.; Bernardo-Filho, M. and Caldeira-de-Araujo, A. (1996). Lethality induced by stannous chloride on Escherichia coli AB1157: Participation of reactive oxygen species. Food Chem Toxicol. 34, 959-962.
Dantas, F. J. S.; Moraes, M. O.; de Mattos, J. C. P.; Bezerra, R. J. A. C.; Carvalho, E. F.; Bernardo-Filho, M. and Caldeira-de-Araujo, A. (1999). Stannous chloride mediates single strand breaks in plasmid DNA through reactive oxygen species formation. Toxicol Lett. 110, 129-136.

de Mattos, J. C. P.; Dantas, F. J. S.; Bezerra, R. J. A. C.; Bernardo-Filho, M.; Cabral-Neto, J. B.; Lage, C.; Leitao, A. C.; Caldeira-de-Araujo, A. (2000). Damage induced by stannous chloride in plasmid DNA. Toxicol Lett. 116, 159-163.

Fonseca, A. S.; Frydman, J. N. G.; Rocha, V. C. and Bernardo-Filho, M. (2005). Acetylsalicylic acid and labeling of blood constituents with technetium-99m. Braz Arch Biol Technol. 48 (Special), 163-168.

Guthrie, H. D. and Welch, G. R. (2007). Use of fluorescence-activated flow cytometry to determine membrane lipid peroxidation during hypothermic liquid storage and freeze-thawing of viable boar sperm loaded with 4, 4-difluoro-5-(4-phenyl-1,3butadienyl)-4-bora-3a,4a-diaza-s-indacene-3undecanoic acid. J Anim Sci. 85, 1402-1411.

Hattori, T. and Maehashi, H. (1989). Stannous chloride induced increase in calcium entry into motor nerve terminals of the frog. Eur J Pharmacol. 166, 527 530.

Hattori, T. and Maehashi, H. (1994). Augmentation of calcium influx by stannous chloride at mouse nerve terminals. Res Commun Chem Pathol Pharmacol. 84, 253-256.

Hayashi, O., Chiba, M., Kikuchi, M. (1984). The effects of stannous chloride on the humoral immune response of mice. Toxicol Lett. 21, 279-285.

Helvig C, Dishman E, Capdevila JH. (1998). Molecular, enzymatic, and regulatory characterization of rat kidney cytochromes P450 4A2 and 4A3. Biochemistry. 37, 12546-12558.

Hengge-Aronis, R. (2000). The general stress response in Escherichia coli. In Bacterial Stress Responses. Edited by Storz G, Hengge-Aronis R. American Society of Microbiology Press, Washington DC, pp.161-179.

Jannini, E. A.; Simonelli, C. and Lenzi, A. (2002). Disorders of ejaculation. J Endocrinol Invest. 25, 1006-1019.

Jesus, L. M.; Abreu, P.R.; Almeida, M. C.; Brito, L. C.; Soares, S. F.; de Souza, D. E.; Bernardo, L. C.; Fonseca, A. S. and Bernardo-Filho, M. (2006). A propolis extract and the labeling of blood constituents with technetium-99m. Acta Biol Hung. 57, 191-200.

Kumar, S., Sathwara, N. G., Gautam, A. K., Agarwal, K., Shah, B., Kulkarni, P. K., Patel, K., Pael, A., Dave, L. M., Parikh, D. J. and Saiyed, H. N. (2005). Semen quality of industrial workers occupationally exposed to chromium. J Occup Health. 47, 424-430. 
Lambreva, E.; Klaghofer, R. and Buddeberg, C. (2006). Psychosocial aspects of patients with sexual dysfunction. Schweig Rundsch Med Prax. 95, 226231.

Lima-Filho, G. L.;Lima, G. M. T.; Freitas, R. S.; Aleixo, L. C. M.; Moreno, S. R. F.; Catanho, M. T. J. A. and Bernardo-Filho, M. (2003). Evaluation of the phytic acid effect on the labeling of elements with technetium-99m and on the survival of a strain of Escherichia coli treated with stannous fluoride. Mol Cell Biochem. 247, 121-126.

Mannel, M. (2004). Drug interactions with St John's wort: mechanisms and clinical implications. Drug Saf. 27, 773-797.

Matin, A. (1991). The molecular basis of carbonstarvation-induced general resistance in Escherichia coli. Mol Microbiol 5, 3-10.

Melo, S. F.; Soares, S. F.; da Costa, R. F.; da Silva, C. R.; de Oliveira, M. B.; Bezerra, R. J.; Caldeira-deAraujo, A. and Bernardo-Filho M. (2001). Effect of the Cymbopogon citratus, Maytenus ilicifolia and Baccharis genistelloides extracts against the stannous chloride oxidative damage in Escherichia coli. Mutat Res. 496, 33-38.

Menezo, Y. J.; Hazout, A.; Panteix, G.; Robert, F.; Rollet, J.; Cohen-Bacrie, P.; Chapuis, F.; Clement, P. and Benkchalifa, M. (2007). Antioxidants to reduce sperm DNA fragmentation: an unexpected adverse effect. Reprod Biomed Online. 14, 418-421.

Naha, N. and Chowdhury, A. R. (2006). Inorganic lead exposure in battery and paint factory: effect on human sperm structure and functional activity. $J$ UOEH. 28, 157-171.

Neagoe, I.; Macri, B. M. and Flonta, M. L. (2004). Hyperici herba extract interaction with artificial lipid bilayers. J Pharm Pharmacol. 56, 1283-1289.

Newall, C.A.; Anderson, L.A. and Phillipson, J.D. (1996). Herbal medicines: a guide for health-care professionals. Pharmaceutical Press: London.

Oliveira, J. F.; Avila, A. S.; Braga, A. C. S.; Oliveira, M. B. N.; Boasquevisque, E. M.; Jales, R. L.; Cardoso, V. N. and Bernardo-Filho, M. (2002). Effect of extract of medicinal plants on the labeling of blood elements with technetium-99m and on the morphology of red blood cells: I- a study with Paullinia cupana. Fitoterapia. 73, 305-312.

Oliveira, J. F.; Oliveira, M. B.; Ávila, A. S.; Braga, A. C. S.; Catanho, M. T. J. A.; Jales, R. L. C.; Cardoso, V. N. and Bernardo-Filho, M. (2003). Assessment of the effects of Fucus Vesiculosus extract on the labeling of blood constituents with technetium-99m and the histological modifications on the shape of the red blood cells. Food Chem Toxicol. 41, 15-20.

Orr, W.C. and Sohal, R.S. (1994). Extension of lifespan by overexpression of superoxide dismutase and catalase in Drosophila melanogaster. Science 263, 1128-1130.
Parkes, T. L.; Elia, A. J.; Dickinson , D.; Hilliker, A. J.;Phillips, J. P. and Boulianne, G. L. (1998). Extension of Drosophila lifespan by overexpression of human SOD1 in motorneurons. Nat Genet 19, 171174.

Rotblatt, M. and Ziment, I. (2002). Evidence-Based Herbal Medicine. Hanley \& Belfus, Philadelphia.

Saha, G. B. (2004). Fundamentals of Nuclear Pharmacy. Springer, New York.

Sosa, S.; Pace, R.; Bornacin, A.; Morazzoni, P.; Riva, A.; Tubaro, A. and Della Loggia, R. (2007). Topical anti-inflammatory activity of extracts and compounds from Hypericum perforatum L. J Pharm Pharmacol. 59, 703-709.

Sun, J.; Folk, D.; Bradley, T.J. and Tower. J. (2002). Induced overexpression of mitochondrial $\mathrm{Mn}$ Superoxide dismutase extends the life span of adult Drosophila melanogaster. Genetics 161, 661-672.

Yousef, M. I. (2005). Protective role of ascorbic acid to enhance reproductive performance of male rabbits treated with stannous chloride. Toxicology. 207, 8189.

Yousef, M. I.; Awad, T. I.; Elhag, F. A. and Khaled, F. A. (2007). Study of the protective effect of ascorbic acid against the toxicity of stannous chloride on oxidative damage, antioxidant enzymes and biochemical parameters in rabbits. Toxicology $\mathbf{2 3 5}$, 194-202.

Wada. A.; Sakaeda, T.; Takara, K.; Hirai, M.; Kimura, T.; Ohmoto, N.; Zhou, J.; Nakamura, T.; Kobayashi, H.; Okamura, N.; Yagami, T. and Okumura, K. (2002). Effects of St John's wort and hypericin on citotoxicity of anticancer drugs. Drug Metab Pharmacokinet. 17, 467-474.

Wang, Z.; Gorski, J. C.; Hamman, M. A.; Huang, S. M.; Lesko, L. J. and Hall, S.D. (2001). The effects of St John's wort (Hypericum perforatum) on human cytochrome P450 activity. Clin Pharmacol Ther. 70, 317-326.

Werneke, U.; Horn, O. and Taylor, D. M. (2004). How effective is St John's wort? The evidence revisited. $J$ Clin Psychiatry. 65, 611-617.

Woelk, H. (2000). Comparison of St John's wort and imipramine for treating depression: randomized controlled trial. Br Med J. 321, 536-539.

Wood, J. M. (1974). Biological cycles for toxic elements in the environment. Science 183, 10491052.

Wu, W., Zhang, Y. and Zhang, F. (1996). Studies of semen quality in workers exposed to manganese and electric wedding. Zhonghua Yu Fang Yi Xue Za Zhi. 30, 266-268. 